\title{
Obecná pedagogika a dějiny pedagogiky - proměny dějin pedagogiky ve vztahu k obecné pedagogice
}

\section{Štefan Chudý, Pavel Neumeister}

\begin{abstract}
Abstrakt
Text příspěvku je zaměřen na problematiku uchopování obecné pedagogiky a dějin pedagogiky jako specificky koncipovaných věd. Přistupuje k procesu konstituování těchto věd z pozic analýzy konstrukcí jejich obsahu a hledá kořeny a nástroje jejich legitimace prostřednictvím vzájemného vztahu.
\end{abstract}

Klíčová slova: věda, legitimace vědy, formální ontologie, velké vyprávění

\begin{abstract}
This paper is focused on the problem of construction of General Theory of Education and History of Education as the social sciences. The first aim of this paper is to approach the process of constituting of these sciences in the point of view of the analysis of the constructions of their content. The second one is searching the roots of its constitution and the instruments of its legitimizing through describing their mutual relations.
\end{abstract}

Key words: science, legitimizing, formal onthology 


\section{Úvod}

Koncept tohoto textu vznikl jako diskusní príspěvek v rámci odborného seminář, věnovaného problematice obecné pedagogiky, který se konal v Olomouci v únoru tohoto roku. Jedná se o rozšířené pojetí původní myšlenky o vzájemném provázání obecné pedagogiky a dějin pedagogiky, které se snaží reflektovat a zodpovědět otázky, kladené nám, coby autorům ostatními účastníky uvedeného semináře. Cílem příspěvku je poukázat na vztah obecné pedagogiky a dějin pedagogiky jako dvou vzájemně dle našeho názoru pevně provázaných oblastí nejen pedagogiky coby vědy, ale zároveň také pedagogiky jako specifické oblasti pregraduální prípravy. Příspěvek se pokouší z vybraných teoretických pozic znovu promyslet elementární charakteristiky dvou oblastí věd o výchově a na základě jejich proměn poukázat na jejich vzájemnou provázanost. Za významný impuls pro podobu tohoto textu je také skeptická studie J. Hábla Pedagogika a metanarace: pro a navzdory postmoderní situaci.

\section{Obecná pedagogika jako vědní disciplína}

Obecná pedagogika je elementárně charakterizována „jako disciplína pedagogické vědy vytvářející teorii o základních jevech, procesech a subjektech edukační reality, dále pak jako metodologie jejich zkoumání a objasňování. Je nadstavbou nad speciálně pedagogickými disciplínami, pro které by měla definovat jasné pojmy, jednoznačné termíny, vyhodnocovat a doporučovat metody exaktního zkoumání předmětu pedagogické vědy". Takto definuje obecnou pedagogiku J. Průcha v Pedagogické encyklopedii (Průcha, 2009, s. 645).

První problém, který považujeme za nutné zmínit a zpracovat je důraz na kategorii obecná. Obecná pedagogika a její charakter je historicky založen v konceptu J. F. Herbarta, který ji prostřednictvím svého základního spisu Allgemeine Pädagogik aus dem Zweck der Erziehung abgeleitet (Obecná pedagogika odvozená z cíle výchovy), fakticky formuloval jako svébytnou vědní disciplínu. Herbartův důraz na vědecké pojetí obecné pedagogiky je vyjádřen již v samotném pojmu obecná. 'Obecnost pedagogiky jako vědy vyjadřuje následující principy:

a) Obecná platnost pedagogické teorie vystavěné na př́sně vědecké terminologii, sjednocující jednotlivé výchovně vzdělávací aktivity v návaznosti na filosofii jako

\footnotetext{
1 Je zajímavou skutečností, že pojem obecná pedagogika (Allgemeine Pädagogik) sám Herbart ve svém díle nepouživá. Pokud uživá pojem pedagogika, pak tak činí bez adjektiv. $Z$ této skutečnosti a $z$ toho, že $v$ jeho díle není centrálním pojmem pedagogika, ale výchova žáka, lez usuzovat, že Herbart užívá pojem obecná, aby zdůraznil obecnost, univerzálnost nově koncipované vědy, ve srovnání s konkrétními pedagogikami, zabývajícími se jednotlivými vzdělávacími prostředky.
} 
vědou abstrahující obecné zákony a psychologii jako metodou zkoumání lidské psychiky.

b) Obecná platnost pedagogické praxe založené na pedagogické teorii, tedy obecná platnost výchovného vyučování jako směřování k univerzálním principům kultivace lidského jedince.

Herbartovo vymezení pedagogiky jako obecně platné teorie nejlépe vystihuje jeho pojetí výchovného působení. Herbart píše:„Výchovu máme ve své moci, když do mladé duše umíme vštípit velký a svými částmi těsně spjatý myšlenkový okruh, který má sílu překonat, co je v okolí nepríznivého, pojmout, co je př́znivé a spojit to v celek". (Herbart, 1885, s. 13-14.) Touto charakteristikou zároveň Herbart zakládá obecnou pedagogiku jako klíčovou disciplínu, jejímž smyslem je vytvářet trvalý základ pedagogického myšlení, jako svébytný soubor elementárních poznatků, strukturující veškeré další pedagogické poznatky $v$ jednotný systém.

Abychom pochopili specifika role obecné pedagogiky a problémy spojené $s$ jejím vymezováním, zaměřme se nejprve na úvodní otázku vymezení pedagogiky jako vědy. Je pedagogika jako sociálně-humanitní obor vědou? Při charakteristice výzkumného pole pedagogiky můžeme navázat na pojetí tzv. faktuálních věd Maria Bungeho. Dle Bungeho je systém faktuální vědy založen na těchto proměnných:

První proměnnou - definičním znakem výzkumného pole pedagogiky je vědecké společenství, sdílející, zakládající a rozvíjející tradici výzkumného zaměěení. Toto vědecké společenství musí být, jako další definiční znak, společností respektováno a podporováno v jejích specifických aktivitách, čímž společnost vědecké komunitě přiznává určitý společenský status. Dalším definičním znakem je předmětná oblast výzkumu, skládající se z výhradně reálných entit. Tato předmětná oblast musí být zároveň založena na specifickém filosofickém pozadí, obsahujícím konkrétní ontologické, epistemologické a etické principy. Podmínkou vymezení předmětové oblasti je zároveň její formální pozadí, založené na formálních (formálně-logických či matematických) teoriích, které mají členové vědeckého společenství $k$ dispozici. Dalším definičním znakem je specifické pozadí výzkumného pole, tedy soubor relevantních a potvrzených dat, hypotéz a teorií a přiměřených výzkumných metod, které jsou obsaženy ve výzkumných polích relevantních pro dané výzkumné pole. Toto specifické pozadí je zároveň navázáno na fond vědění výzkumného pole, tedy souhrn testovatelných teorií, hypotéz a dat kompatibilních s teoriemi, hypotézami a daty specifického pozadí. Zaměřme se na roli obecné pedagogiky v rámci vymezení výzkumného pole pedagogiky jako faktuální vědy (srv. sec. cit. Bunge in Černík, Viceník 2004, 15-17).

Z hlediska výše uvedených specifik můžeme obecnou pedagogiku charakterizovat především jako oblast vytvářející fond vědění, jako prvotní fond vědění výzkumného pole strukturující specifické výzkumné pozadí konkrétních členů vědeckého společenství. Zkoumáme-li pojetí obecné pedagogiky prezentované v kličových českých či 
slovenských odborných publikacích, zjištujeme, že obecná pedagogika, přesněji její vymezení, podléhá tomuto pozitivistickému definování vědy prostřednictvím samostatného pole předmětu a metodologie zkoumání. V tomto pojetí je proces konstituování obecné pedagogiky jako vědy především systemizováním objektivních poznatků o povaze výchovy a vzdělávání a vztahu výchovy a dalších entit ve zdůvodněném kontextu. Nalezení kontextu, který by zdůvodňoval existenci obecné pedagogiky jako vědy se především projevuje v hledání specifické oblasti působení této vědy, v izolované části sociální reality či specifických oblastech pohledu na tuto realitu. Tato skutečnost se projevuje např́iklad v posteriorních zakládáních obecné pedagogiky jako teoretického východiska již etablovaných postupů vědecké práce či oblasti pomáhajících profesí. Tím se praxe, která by měla svou metodologii odvíjet od přesně vymezených teoretických základů, paradoxně stává základnou pro vznik samostatné teorie.

Odlišným způsobem definování obecné pedagogiky jako oblasti konkrétní vědy je dưraz na konstituování vědy prostřednictvím permanentního zápasu o její legitimitu. Nazírání vědecké relevantnosti obecné pedagogiky z pozice její legitimity rozšiřuje definiční znaky uváděné $M$. Bungem, které je možná charakterizovat otázkou „Nakolik jsou tyto definiční znaky pole faktuální vědy přítomny?" o oblast uznání důvěryhodnosti obsahu těchto definičních znaků, vyjádřitelných otázkou „Proč právě tyto obsahy jako kritéria naplňují definičních znaků vědy?).

Zabývat se problematikou konstituování a legitimity existence obecné pedagogiky s sebou nese určité skryté nebezpečí. Nebezpečí, že k problému přistoupíme z teoretických pozic dané vědy a tím de facto její existenci a priori přijmeme. Jistou míru nezávislosti v přistupování k danému úkolu nabízí vnímání obecné pedagogiky jako sociální konstrukce. Termín sociální konstrukce vědomě prosazuje aktivní přístup jedince k okolní realitě, která není vnímána jako objektivně daná, ale naopak je produktem lidské činnosti, který je vytvářen, přetvářen a získává svůj význam prostřednictvím interpretací, které mu lidé ve vzájemných interakcích přikládají. V tomto pojetí je obecná pedagogika nikoliv objektivně danou vědou, ale systémem, který vzniká, je vytvářen jako výsledek lidských interakcí, je relativně ustáleným způsobem uchopování a přístupu ke konkrétní sféře lidské či „vědecké" praxe. Konstruktivistický přístup zároveň akcentuje význam či vliv sociálního prostředí procesu konstituování vědy, nebot doplňuje obvyklou otázku jaká jsou specifika obecné pedagogiky otázkou, kdo tato specifika vytváŕí a určuje. Proto je nutné obecnou pedagogiku vnímat především jako soubor definičních znakư, které významní aktéři „vědci - pedagogové“ v rámci sociální reality vnímají a ve vzájemných interakcích je objektivizují, habitualizují a typizují. Prostřednictvím procesu habitualizace a typizace se daný objekt stává ustáleným modelem, souborem znaků, kterými je odlišitelný od ostatních objektů, ostatních vědních disciplín. Objektivace znaků je založena na jazyku, který vtiskuje danému sociálnímu světu, ve kterém daná podoba či dané podoby vědy vznikají, vnitřní konzistenci a logiku (Berger, Luckmann, 1999, s. 64-68). 
Na proces objektivace, habitualizace a typizace je dále navázán proces legitimizace, jehož prostřednictvím dochází k etablování dané vědní disciplíny jako důvěryhodné.

Potřebu vytváření legitimizačního rámce dostala obecná pedagogika již při svém vzniku. Tato potřeba legitimizace je dána odkazem z obecné potřeby cíle výchovy, jako centrálního pojmu, který dává smysl jednotlivým postupưm. Jen takové teorie a praktické postupy jsou správné, které směřují k naplnění univerzálního cíle. Univerzálnost tohoto cíle je však také nutné zdůvodnit. Tím se objevuje v Herbartově konceptu obecné pedagogika oblast dějin. Herbart potřebnost dějinné reflexe vnímá jako jeden z klíčových nástrojů vyučování. Herbart zde pracuje s kategorií citové účastenství. Citové účastenství jako výsledek výchovného umění je také základem kultivace osobnosti a probouzení jeho vlastenectví. ${ }^{2}$ Hlavním nástrojem citového účastenství má být dle Herbarta výuka prostřednictvím vhodných př́kladů čerpaných z historie.

Využití historičnosti jednotlivých edukačních cílů vytváŕí jejich legitimizační rámec. V (obecných) pedagogikách založených na kategorii cíl, je zařazení historického popisu či odkaz na oblast pedagogiky klíčové. Vhodným historickým exkursem je zdůvodňována obecná platnost konkrétních hodnot a principů, definovaných jako cíle výchovy. Dějiny pedagogiky tak vytvářejí oblast tzv. velkých vyprávění, meta-narací, které z dějin pedagogiky přesahují do obecné pedagogické teorie. Pojem metanarace (méta récit, grand narrative, velká vyprávění) patři mezi ústřední kategorie lingvistické kritiky dějepisectví. V širším smyslu jde o narace, jejímž základem je směřování historických procesů k danému, mimo historický vývoj stojícímu cíli. Jean-François Lyotard použil kategorii méta récit při kritice osvícenské vize pokroku. Ztráta významu metanarací je pak dle Lyotarda charakteristická pro období postmoderny. Metanarace se musí prosadit ve společnosti vůči jiným, konkurenčním metanaracím, což otvírá otázku po jejich nositelích, kteří soupeří o hegemonii nad výkladem minulosti (Lyotard, 1993, s. 132-133).

Další francouzský filosof, který rozpracoval kategorii metanarace, Paul Ricoeur, chápe metanaraci jako složitější strukturální faktor, jehož prostřednictvím dochází k selektivitě historického vyprávění, proměna zdánlivé nahodilosti historických událostí v objektivní historické kauzality, způsob vytváření oficiálních linii vývoje.(Ricoeur, 2000, s. 213).

Meta-narace po celá staletí zajištovala integritu lidských pospolitostí a smysluplnost konkrétně prožívané reality. „Každá kultura byla semknuta kolem příběhu, který byl společně sdílen, předáván a tradován. Zároveň veškeré pojmy a hodnoty získávaly svou legitimitu od sdíleného př́iběhu" (Hábl, 2012, s. 88). Zároveň tak velká (pedagogická) vyprávění sdružená kolem centrální kategorie cíl výchovy zajištují integritu soudržnosti pedagogické teorie a její smysluplnost ve vztahu k užitým výchovně vzdělávacím prostředkům. Klíčovým úkolem je stanovování jejich determinace na straně jedné a účelnosti na straně druhé. Můžeme tedy obecně konstatovat, že se jedná o soubor

2 Herbart vydává svou Obecnou pedagogiku v době existenčního ohrožení Německa napoleonskou Francií. Právě uvedená hrozba se stala také základem rozmachu pangermánského nacionalismu (poznámka autorů). 
pravidel, která interpretují či reinterpretují dějinné události jako kontinuální proces, řízený vyšším principem či smyslem a vytvářejí instance vymezování jednotlivých událostí jako významných či nevýznamných. (Ricoeur, 2000, 221-222). Identifikace s obecným cílem, podpořená velkým vyprávěním zakládá normativní charakter obecné pedagogiky. Objektivitu vědeckého poznání ztotožňuje s naplněním předem daného cíle, kterým mohou být dobově platné ideje emancipace společnosti, společenské třídy, národa či jednotlivce a s tím spojená idea historické nevyhnutelnosti edukačních cílů.

\section{Moderní „obecná“ pedagogika mezi velkým vyprávěním a formální ontologií}

Zásadní změnou pojetí obecné pedagogiky bylo odmítnutí marxistického pojetí pedagogiky v souvislosti se změnami po roce 1989. Odmítnutí marxistické pedagogiky směřující k univerzálními cíli socialistické výchovy jako evolučně nejvyššího stupně výchovy ve společnosti a zároveň odmítnutí velkých vyprávění, tuto ideu podporující, přineslo potřebu nově koncipované obecné pedagogiky. Relevantním řešením bylo koncipování nové, tzv. moderní pedagogiky. Základní charakteristikou tohoto nového konceptu, zakotveného především ve stejnojmenné publikaci J. Průchy, byl zásadní odklon od normativního definování pedagogiky, předepisující a doporučující optimální podobu (Průcha, 1997, s. 9) a zdůrazňuje svou roli při formování lidstva, v některých př́padech až spasitelské. Naopak moderní pedagogika má být založena na explanačním př́stupu, který hledá, objasňuje a staví výklad na zjištěných faktech.

Tato změna pojetí odpovídá zásadní diskursivní proměně vzdělávání učitelů po roce 1989 spočívající v implementaci přístupů založených na výkonu (performance-based) přinesla do českého školství novou obecnou kategorii kompetence - hovoří se o kompetencích žáků, o kompetencích učitelů. Ústřední myšlenkou této změny je přechod od hodnocení výstupů vzdělávání prostřednictvím míry osvojení předepsaných obsahů k hodnocení prostřednictvím profesních kompetencí - konkrétních kritérií chování, konkrétních výkonů (Janík, 2005). Nejednotné definování profesních kompetencí učitele zahrnující výčty způsobilostí, vlastností učitelů, dovedností atd. sumarizuje T. Janík ve smyslu komplexní potencionality k úspěšnému „efektivnímu“ vykonávání učitelské profese (Janík, 2005). Jednou z klíčových rovin či komponent spoluvytvářejících profesní kompetenci učitele jsou také subjektivní teorie učitele (učitelovy implicitní teorie) (Clark, Peterson 1986) či učitelovo přesvědčení (teacher beliefs). Právě proces utváření a proměn subjektivních teorií učitele v procesu pregraduální prípravy učitelů jako specifického souboru poznatků ( $v$ užším pojetí) jsou svébytnou doménou obecné pedagogiky jako disciplíny. Vycházíme přitom z přesvědčení, že subjektivní teorie jsou obsahem vnitřního světa významů člověka, které si jedinec v souladu s pravidly fenomenologické filosofie vytváří na základě zakoušení tohoto světa. Většinové pojetí 
subjektivních teorií naopak přistupuje k pojetí člověka jako vědce a subjektivní teorie charakterizuje obdobně jako „vědecké" teorie prostřednictvím stupně systematičnosti, argumentační struktury či jazykové formulovatelnosti. Tím ovšem subjektivní teorii degradujeme na protiklad teorii vědecké a proces pregraduální prípravy je pak vnímán jako posun od subjektivní teorie $\mathrm{k}$ vědecké teorii či rekonstrukce subjektivních teorií $v$ teorie vědecké. $V$ hotové podobě jsou pak prezentovány jako soubory předem daných informací v rámci úvodní disciplíny do pedagogických věd, které mají v české pedagogice pojetí tzv. obecné pedagogiky. Obecná pedagogika je tradičně proto pojímána jako systémová pedagogika, jako centrální disciplína s normativní kontrolou na ostatními disciplínami pedagogiky, jejímž úkolem je provádět syntézu poznání a generovat obecnou teorii edukace (Lenzen, 1998). Cílem této disciplíny je postavit studenta učitelství na konkrétní obsahovou a významovou základnu, vybavit jej pojmy, kterými budou přenositelné jednotlivé obsahy věd o výchově.

Toto pojetí vzdělávání nejlépe vystihuje pojem formální ontologie. Přestože je ontologie původním filosofickým pojmem, charakterizující problematiku jsoucna (entity) a bytí (being), je v současné době preferována především v oblasti informatiky jako formalizovaná reprezentace znalostí určená k jejich sdílení a znovupoužití. Principem formální ontologie v informatice je tedy vytvářet struktury a nástroje společného sdílení uznávaných popisů jednotlivých entit. Proč v této studii použivám pojem formální ontologie? Je to proto, že současné pojetí obecné pedagogiky v rámci pregraduální prípravy učitelů plní úlohu formální ontologie, tedy vytváření obecného ontologického datového modelu, který a) je formalizovanou reprezentací znalostí určených k jejich sdílení, b) je to sdílená terminologie pro určitou aplikační sféru, c) je reprezentací konceptu založenou na všeobecně sdílené významové struktuře a terminologii dané sféry. (Svátek, Ontologie a WWW, s. 1-2) Př́klon moderní pedagogiky k argumentaci založené na explanaci, popírající normativní charakter, jejímž cílem je vytvořit jednotný ontologický model reprezentující znalost, však postrádá smysl odvozený z obecného příběhu. Jediným adekvátním přiběhem je liberalistické pojetí kompetentního absolventa, jehož výkonnost je klíčovým měřítkem jeho kvality. $V$ tomto pojetí je zároveň potlačována oblast dějin pedagogiky, jako nepotřebné a z hlediska pregraduální prípravy učitelů neefektivní. Spolu s potlačením dějin pedagogiky tak dochází k oslabování smysluplných vyprávění, která přispívají k formulování smyslu pedagogické praxe a jsou součástí učitelova presvědčení.

\section{Závěr}

V uvedeném textu jsme se pokusili poukázat na provázanost oblasti obecné pedagogiky a dějin pedagogiky. Prokázali jsme, že „obecnost“ obecné pedagogiky byla již od svého vzniku podmíněna velkým vyprávěním, nalézajícím svou argumentační bázi ve výkladu 
historie. Proto také v minulosti byla oblast obecné pedagogiky vždy těsně provázána s oblastí dějin pedagogiky. Odmítnutí velkých vyprávění zakládajících normativnost obecné pedagogiky a směřování k explanačnímu pojetí vědy znamená naopak vyprazdňování smyslu existence studia. Bez velkých vyprávění založených na dějinách pedagogiky ztratí obecná pedagogika svou obecnost, přestane být zastřešující vědní disciplínou v oblasti věd o výchově. S velkými vyprávěními bude naopak podezřívána z ideologické tendenčnosti a popírána pro svou nevědeckost.

Výzkumný záměr fakulty PdF UP: Od subjektivních implicitních teorií výchovy ke znalosti učitele. Proces konstituování kognitivních rámců věd o výchově v národním a mezinárodním kontextu.

IGA PdF 2014025: Metanarativní funkce dějin pedagogiky v českém pedagogickém myšlení 20. století

\section{Literatura}

Berger, P. L., Luckmann, T. (1999). Sociální konstrukce reality. Praha: Centrum pro studium demokracie a kultury.

Clark, C. M., Peterson, P. L. (1986). Teachers thought processes. In Wittrock, M. C. (ed.). Handbook of research on teaching. London: MacMilllan.

Černík, V., Viceník, J. ed. (2004). Problém rekonštrukcie sociálnych a humanitních vied. Bratislava: Iris. Hábl, J. (2012). Pedagogy and Metanarratives: Educating in the Postmodern Situation. e-Pedagogium, IV/2012.

Herbart, J. F. (1885). Allgemeine Pädagogik aus der Zweck der Erziehung abgeleitet. Leipzig:Verlag von Siegismund und Bolsening.

Janík, T. (2005). Znalost jako klíčová kategorie učitelského vzdělávání. Brno: Paido.

Lenzen, D. (1998). General Theory of Education; A Subdiscipline or the Central Discipline of Educational Studies? Education 56, 2, pp. 77-98.

Lyotard, J. F. (1993). Postmoderní situace. In O postmodernismu. Praha: Filosofický ústav AV ČR.

Průcha, J. (1999). Moderní pedagogika. Praha: Portál.

Průcha, J. ed. (2009). Pedagogická encyklopedie. Praha: Portál.

Ricoeur, P. (2000). Čas a vyprávění. Praha: OIKOYMENH.

\section{Kontakt na autora:}

doc. Mgr. Štefan Chudý, Ph.D.

Mgr. Pavel Neumeister, Ph.D.

ÚPSS PdF Univerzita Palackého v Olomouci

Žižkovo nám. 5

77140 Olomouc

Tel.: 585635154

E-mail: pavel.neumeister@upol.cz; stefan.chudy@upol.cz 